\title{
Synthesis and Investigation of Polyimide-based Proton-exchange membranes Containing Polysiloxane and Crown Ether Moiety
}

\section{VITALY SERGEEVICH IVANOV, ANTON SERGEEVICH YEGOROV*, GRANT RANTOVICH ALLAKHVERDOV and VLADIMIR VIKTOROVICH MEN'SHIKOV.}

\author{
The Federal State Unitary Enterprise «Institute of Chemical Reagents and High Purity Chemical \\ Substances of National Research Centre «Kurchatov Institute» (NRC «Kurchatov \\ Institute» - IREA.),107076, Bogorodsky val, 3. Moscow, Russia. \\ ${ }^{\star}$ Corresponding author E-mail: egorov@irea.org.ru
}

http://dx.doi.org/10.13005/ojc/340128

(Received: October 04, 2017; Accepted: December 25, 2017)

\begin{abstract}
ABSTACT
In present work, a number of polyimides contained polysiloxane and crown-ether moiety in the main chain were synthesized. Solubility in organic solvents and film-forming ability were investigated. Prepared polymers are insoluble in low boiling solvents and highly soluble in $\mathrm{m}$-cresol, NMP and DMSO. Strong films were prepared with NTDA monomer, with the exception of the PI of the composition BNTDA-BDSA. Thermal properties of films were studied in comparison with corresponding powders. All prepared films demonstrated a sufficiently high thermal stability and suitable for design of low-temperature fuel cells (up to $100{ }^{\circ} \mathrm{C}$ ) and can be used for medium temperature fuel cells $\left(140-200^{\circ} \mathrm{C}\right)$. The mechanical properties of the prepared strong films were also examined.
\end{abstract}

Keywords: Proton-exchange (electrolytic) polymer membrane (PEM), Polyimides, Sulfonated polyimide (SPI), Naphthalic polyimides, Poly(imide-siloxane), Crown-ether inclusion.

\section{INTRODUCTION}

Fuel cells (FC) are devices that generate electricity through chemical reaction of fuel with oxygen and attracts increasing attention of alternative energy researches as they do not produce any harmful emissions to the environment ${ }^{1-3}$. The main difference between fuel cells and other chemical power sources is the ability to provide continuous fuel supply and current takeoff within potentially unlimited time. However, there is apparent degradation of all MEA components which leads to monotone voltage reduction and decreasing of efficiency in fuel cells ${ }^{3-6}$.

Membranes are the most complicated and expensive part of a fuel cell, which also limits fuel cell capabilities. Under regular exposure to

This is an $\mathbf{C}$ Open Access article licensed under a Creative Commons Attribution-NonCommercial-ShareAlike 4.0 International License (https://creativecommons.org/licenses/by-nc-sa/4.0/ ), which permits unrestricted NonCommercial use, distribution and reproduction in any medium, provided the original work is properly cited. 
aggressive environment membranes gradually deteriorate during FC operation. Such deterioration is indicative for the proton-exchange membrane fuel cells (PEM FC) ${ }^{7-9}$.

Nowadays the most widespread membranes are perfluorinated polymers, which are considered as "classic» FC membranes. These membranes possess high mechanical strength, excellent chemical resistance and high proton conductivity (e.g. Nafion DuPont) ${ }^{10}$. However, there are several substantial drawbacks which hinder their large-scale commercial application, i.e. high cost, low operating temperatures, high fuel flows and significant environmental footprint ${ }^{11}$.

Alternative commercially available systems, which can be used at temperatures up to $200^{\circ} \mathrm{C}$ is phosphoric-acid-doped polybenzimidazole-based membranes (Celtec Division's PEMEAS membranes) $)^{12-14}$.

One of the major issues for researches are tracking and development of alternative PEMs focused on nonfluorinated or partially fluorinated polymers ${ }^{15-20}$. These membranes must possess high proton conductivity (or comparable for fluorinated membranes) and also chemical and physical stability in FC operation environment at moderate temperatures $\left(70-140^{\circ} \mathrm{C}\right)$, while the optimization of these characteristics must be carried out in a comprehensive manner, since they are very closely related to each other ${ }^{4-6,15,21}$.

One of the promising materials for manufacturing FC membranes is aromatic polyimides $(\mathrm{PI})^{22-23}$. Polyimides are featured by high heat resistance, especially polyimides based on pyromellitic acid dianhydride and 1,4,5,8naphthalenetetracarboxylic acid dianhydride and do not melts up to thermal decomposition ${ }^{24}$.

The performance of sulfonated naphthalic polyimides (SPI) (containing hexatomic imide rings in their chains) for the fuel cells are comparable to those of Nafion operating for up to 3000 hours. However, the characteristics of the membranes based on sulfonated phthalic polyimides (containing five-membered imide rings in their chains) significantly deteriorate even after $70 \mathrm{~h}$ operation ${ }^{25}$.
While the first generation of SPI electrolytes demonstrated electrical conductivity range from $2 \cdot 10^{-3} \mathrm{~S} / \mathrm{cm}$ to $4 \cdot 10^{-2} \mathrm{~S} / \mathrm{cm}, 26,27$ which were significantly lower than those of Nafion, the next generation of SPI electrolytes showed satisfactory conductivity values of up to $1.67 \mathrm{~S} / \mathrm{cm}$ at $120^{\circ} \mathrm{C}{ }^{28}$ and $1.201 \mathrm{~S} / \mathrm{cm}$ at $80{ }^{\circ} \mathrm{C}$ respectively for SPI/ graphene composite material.

Solubility of the polyimides strongly depends on a chemical structure of the polymer. There are two key factors of soluble polyimide synthesis: decreasing the regularity (unit repeatability) of the backbone and minimizing the density of imide rings alongside the backbone. A large number of structural changes, including incorporation of thermally stable, flexible and nonsymmetrical units and bulky substituents ${ }^{11}$ were explored in the past decades. Polyimides containing bulky triphenylamine units alongside a polymer's backbone chain are amorphous materials and demonstrated high solubility, exceptional filmforming ability as well as high thermal stability ${ }^{29-31}$.

Copolymerization is one of the most widely used and effective methods for producing of the new polymers with desired properties due to presence of several structures possessing with different chemical or physical properties within a single polymer chain. Improving the efficiency of FC operation requires developing block-structured polymer electrolytic membranes (block copolymers), where each repeating polymer block performs a particular function and provides materials with unique properties unpossessable by standard polymers.

One of widespread and suitable type of block for PI chain is polydimethylsiloxanes ${ }^{32}$. The characteristics of linear polydimethylsiloxanes fits with requirements for PEM FC. Polydimethylsiloxane (PDMS) is one of the most widespread polydimethylsiloxane, which possesses very high polymer chain flexibility among synthetic polymers. Another important advantage of polydimethylsiloxanes is thermal resistance and oxidation stability, which are similar to those of polyimides

We synthesized a number of polyimides accompanied by adding polysiloxane fragments and crown ethers to their backbone for low 
temperature polymer electrolytic (proton-exchange) membranes. The solubility in typical organic solvents and film-forming ability were investigated. Number of the prepared polymers form hard solution-based films. Thermal and mechanical properties of the prepared films were analyzed as well.

\section{EXPERIMENTAL}

\section{Materials}

1,4,5,8-naphthalenetetracarboxylic acid dianhydride (NTDA, 98\%, Sigma Aldrich), 4,4'- oxydianiline (ODA, 97\%, Vekton), dimethy sulphoxide (DMSO, 99\%, Vekton), benzoic acid (BA, $97 \%$, Vekton), acetone (98\%) and ethanol (95\%) were used without additional purification, while m-cresol was (97\%) distilled in advance. Solvents for solubility investigation were purchased from the CJSC «Vekton». 1,3-bis(3-aminopropyl) tetramethyldisiloxane (PDMS) was synthesized by procedure described in the ref. ${ }^{33} .4,4$ '- Binaphthyl$1,1^{\prime}, 8,8$ '- tetracarboxylic (BNTDA) dianhydride was synthesized by procedure described in reference ${ }^{34}$ with modifications. Diaminodibenzo-18-crown-6 (DADB-18-C-6) was prepared using by method described in reference. ${ }^{35,36}$ with modification Triethylammonium salt of 4,4'-oxydianiline-2,2'disulphonic acid (BDSA) was synthesized by the method described in ref. ${ }^{37}$. 4-[4-(4- Aminophenoxy) phenoxy]phenylamine (P-APPA) was synthesized by method described in ref $^{38,39}$. The preparation method of bis(ammoniophenyl) phosphinic acid (4-APPA) dichloride was described in ref. ${ }^{40}$. 3,3',4,4'- Benzophenone tetracarboxylic (BPDA) dianhydride was produced by the method described in ref. ${ }^{41}$ (see also Table. 1 ).

\section{Polyimide synthesis}

A single-stage method with $\mathrm{m}$-cresol as solvent was used for preparation of polyimides ${ }^{42}$. Appropriate amount of diamines were placed into 100-ml three-neck round-bottomed flask equipped with magnetic stirrer, argon inlet, reflux condenser and argon outlet (Table. 2). (When bis-ammoniophenyl) phosphinic acid dichloride was used, 2.4-fold excess of triethylamine (TEA) and $m$-cresol were added to turn it into diamine). The substances were mixed for complete diamines dissolution followed by addition of dianhydride (Table. 2) and benzoic acid (0.5 g, $0.004 \mathrm{~mol})$. The substances were stirred for $10-15 \mathrm{~min}$. at room temperature, heated with the oil bath up to $80{ }^{\circ} \mathrm{C}$ and stirred for $4 \mathrm{~h}$, then heated and stirred for $20 \mathrm{~h}$ at $180{ }^{\circ} \mathrm{C}$.

Upon completion of the stirring at $180{ }^{\circ} \mathrm{C}$ the reaction mass was cooled down to $80-100{ }^{\circ} \mathrm{C}$ and poured into acetone without dilution. To ensure better separation of solvents and polyimides the substances were mixed and heated at $50{ }^{\circ} \mathrm{C}$ for 30 minutes. Precipitate was filtered-off, flushed with ethanol, transferred in beaker and stirred at $60{ }^{\circ} \mathrm{C}$ for 30 minutes. The PI precipitate was filtered-off and dried in vacuum at $100^{\circ} \mathrm{C}$ until constant weight.

DA-18-C-6 (0.9 g, 0,0023 mol), BDSA (1.4g, $0.0025 \mathrm{~mol})$ PDMS (0.07 g, $0.0003 \mathrm{~mol}$ ) and of $m$-cresol (32 ml) were placed into $100-\mathrm{ml}$ threeneck round-bottom flask equipped with magnetic stirrer, argon inlet, reflux condenser and argon outlet. The substances were stirred to complete diamines dissolution followed by addition of NTDA (1.34 g, $0.005 \mathrm{~mol})$ and benzoic acid $(0.5 \mathrm{~g}, 0.004$ $\mathrm{mol})$. The mixture was stirred for $10-15 \mathrm{~min}$. at room temperature, heated with oil bath at $80{ }^{\circ} \mathrm{C}$ and kept for $4 \mathrm{~h}$ heated at $180^{\circ} \mathrm{C}$ and stirred for 20 hours.

Upon completion of the reaction the reaction mass was cooled down to $80-100{ }^{\circ} \mathrm{C}$ and poured into $300-\mathrm{ml}$ acetone. To ensure better separation of solvent and polyimides the substances were stirred and heated at $50{ }^{\circ} \mathrm{C}$ for $30 \mathrm{~min}$. Precipitate was filtered off, transferred into beaker, flushed with 300-ml ethyl alcohol and heated at $60{ }^{\circ} \mathrm{C}$ with stirring for 30 minutes. The PI precipitate was filtered off and dried in vacuum at $100{ }^{\circ} \mathrm{C}$ until constant mass.

\section{Investigation of the solubility of $\mathrm{PI}$ produced}

A set of dissolution tests using common organic solvents was carried out to investigate the solubility of $\mathrm{PI}$ powders (Table. 3). PI powder $(0.005 \mathrm{~g})$ and $1 \mathrm{ml}$ of the solvent were mixed in the serum vial. Resulted solutions were heated up to the boiling and visually exanimated for the solubility. 


\section{Polyimide film production}

After suitable solvent selection, polyimide solutions with different concentrations were prepared (Table. 3). The solutions kept for $1 \mathrm{~h}$ under stirring in the oil bath at $140-150{ }^{\circ} \mathrm{C}$. Once cooled down, the solutions were poured onto $90 \times 120-\mathrm{mm}$ standard glass plates for coating tests, preliminary defatted with acetone.

\section{Polymer description}

NMR spectra were recorded with FourierTransform Spectrometer Bruker Avance III Nanobay $300 \mathrm{MHz}$, Bruker Biospin;

The degree of imidization was determined with Fourier-transform infrared spectra of the powdered polyimides to estimate reaction yield. Absorption spectra were recorded with Fouriertransform infrared spectrometer. Bruker VERTEX 70 with extended infrared range of 8000 to $50 \mathrm{~cm}^{-1}$ and Fourier-transform Raman module RAMII Bruker Optics.

Thermal analysis was carried out by differential scanning calorimetry (DSC) method according to Russian state standard R 55134-2012 with thermal analyzer SDT Q600 for simultaneous DSC/TGA/DTA analysis TA Instruments

\section{RESULTS AND DISCUSSION}

\section{Polyimide synthesis}

General synthesis scheme of polymer is shown in Fig. 1. Aromatic fragments of used dianhydrides assigned as $Q$, while fragments of used diamines and inclusion compounds assigned as $X, Y$ and $Z$ respectively. The structures of utilized monomeric compounds are demonstrated in Table. 1. The composition of the prepared polyimides is demonstrated in Table. 2.

The amount of $m$-cresol for polyimide synthesis have to be selected with respect to solubility of aimed polyimides and initial monomers. For example, polyimides containing NTDA and dianhydride monomeric units are significantly poorer soluble in $m$-cresol by comparison with containing BNTDA or BPDA monomeric units. Low yield of $\mathrm{PI}{ }^{11} 16$ was caused by difficulties concerning the purification and excessive solvent consumption. As result amount of m-cresol to synthesize PI with BNTDA or BPDA monomeric units was decreased up to 1.5 times in comparison with PI containing NTDA monomeric units.

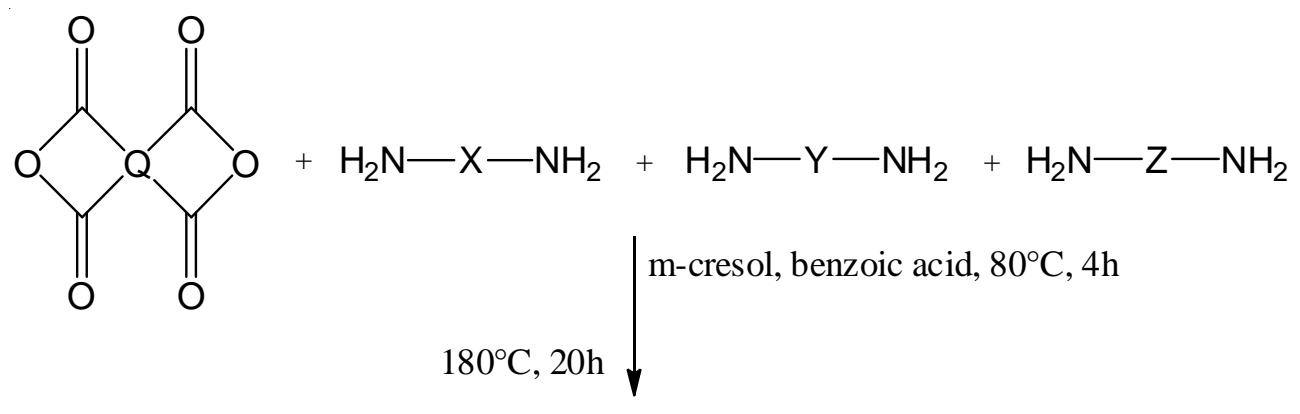<smiles>[Z]N1C(=O)OC1=O</smiles>

Fig. 1. Polyimide-based polymer synthesis 
Table. 1: Diamines, dianhydrides and inclusions used to produce polyimides

\begin{tabular}{|c|c|c|c|}
\hline Abbreviation & IUPAC name & $\begin{array}{l}\text { Chemical } \\
\text { formula }\end{array}$ & $\begin{array}{l}\text { Chemical } \\
\text { structure }\end{array}$ \\
\hline NTDA & $\begin{array}{l}\text { 1,4,5,8 - naphthalenetetracarboxylic } \\
\text { dianhydride }\end{array}$ & $\mathrm{C}_{14} \mathrm{H}_{4} \mathrm{O}_{6}$ & \\
\hline BNTDA & $\begin{array}{l}\text { 4,4'-binaphthyl-1,1', 8,8'-tetracarboxylic } \\
\text { dianhydride }\end{array}$ & $\mathrm{C}_{24} \mathrm{H}_{10} \mathrm{O}_{6}$ & \\
\hline BPDA & $\begin{array}{l}3,3 \text { ', 4,4'-benzophenone tetracarboxylic } \\
\text { dianhydride }\end{array}$ & $\mathrm{C}_{17} \mathrm{H}_{6} \mathrm{O}_{7}$ & \\
\hline BDSA & $\begin{array}{l}\text { Triethylammonium salt of } \\
\text { 4,4-oxididinyl-2,2-disulfonic acid }\end{array}$ & $\mathrm{C}_{24} \mathrm{H}_{42} \mathrm{~N}_{4} \mathrm{O}_{7} \mathrm{~S}_{2}$ & \\
\hline DA18-C6 & Diaminodibenzo-18-crown-6 & $\mathrm{C}_{20} \mathrm{H}_{26} \mathrm{~N}_{2} \mathrm{O}_{6}$ & \\
\hline p-APPA & $\begin{array}{l}\text { 4- [4- (4-Aminophenoxy) phenoxy] } \\
\text { phenylamine }\end{array}$ & $\mathrm{C}_{18} \mathrm{H}_{16} \mathrm{~N}_{2} \mathrm{O}_{2}$ & \\
\hline ODA & 4,4'-Oxidianiline & $\mathrm{C}_{12} \mathrm{H}_{12} \mathrm{~N}_{2} \mathrm{O}$ & \\
\hline DC4-APPA & $\begin{array}{l}\text { Bis (aminophenyl) phosphoric } \\
\text { acid dichloride }\end{array}$ & $\mathrm{C}_{12} \mathrm{H}_{15} \mathrm{Cl}_{2} \mathrm{~N}_{2} \mathrm{O}_{2} \mathrm{P}$ & \\
\hline PDMS & Diaminopropyldimethyldisiloxane & $\mathrm{C}_{10} \mathrm{H}_{28} \mathrm{~N}_{2} \mathrm{OSi}_{2}$ & \\
\hline
\end{tabular}

\section{Description of the PI produced}

Figure. 2 illustrate a fragments of ${ }^{1} \mathrm{H}$ NMR spectrums of the polyimides No 2 and 5 clearly visible signals of triethylammonium cations proves polar ionic structure of synthesized polymers 12 and 14. In addition, signals at $0 \mathrm{ppm}$ are illustrate $\mathrm{CH}_{3}^{-}$ Si of PDMS moiety in PI No 5.

The signals in IR spectra are conforms with proposed structures for all polyimides and exhibit absorption maximum specific to imide groups ( $1775 \mathrm{~cm}^{-1}(\mathrm{C}=\mathrm{O}$ asymmetric stretching), $1712 \mathrm{~cm}^{-1}$ (C=O symmetric stretching), $1368 \mathrm{~cm}^{-1}$ (C-N stretching), and $721 \mathrm{~cm}^{-1}(\mathrm{C}=\mathrm{O}$ bending) is shown. Complete imidization proves by absence of absorption bands at $1660 \mathrm{~cm}^{-1}$ corresponding to $\mathrm{C}=\mathrm{O}$ amide stretching in the FTIR spectra of prepared polyimides.

\section{Solubility}

Various typical organic solvents, such as acetone, ethyl alcohol, toluene, chlorobenzene, chloroform, dichloromethane, acetonitrile, tetrahydrofuran, dioxane, N,N-dimethylformamide (DMFA), dimethylsulphoxide (DMSO), $\mathrm{N}$-methylpyrrolidone (N-MP), N,N-dimethylacetamide (DMAC) were used for solubility investigation. 
YEGOROV et al., Orient. J. Chem., Vol. 34(1), 255-264 (2018)

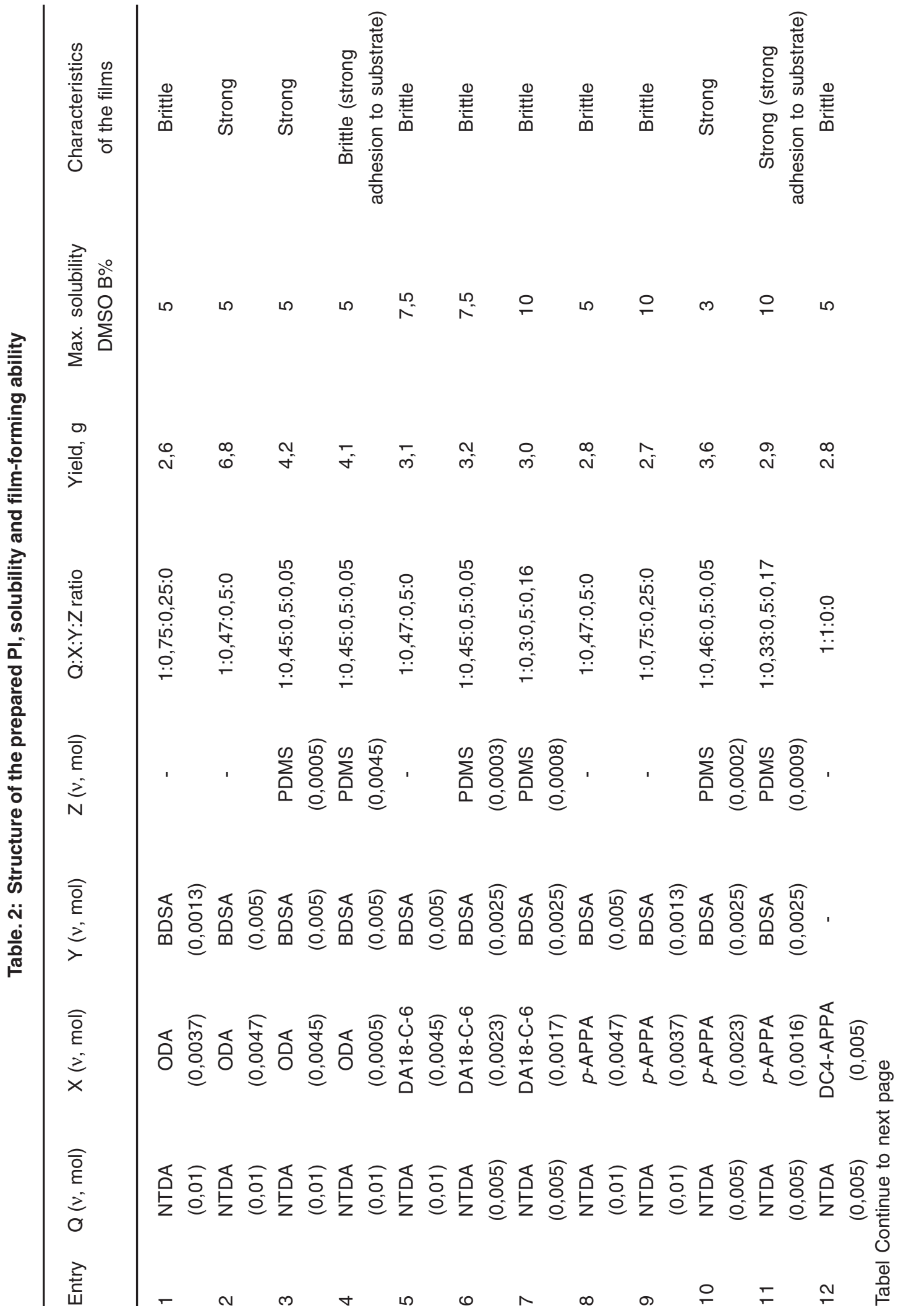


喜

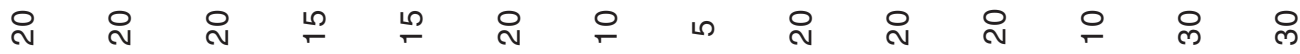

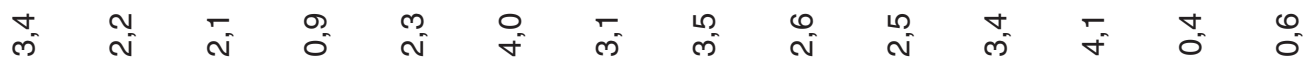

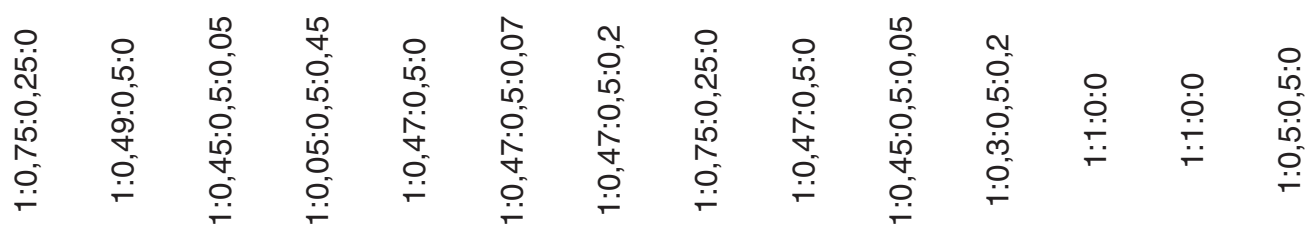

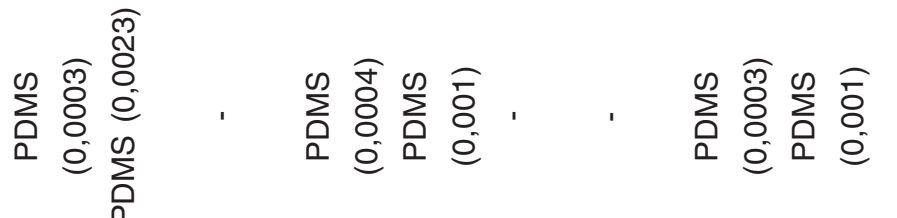

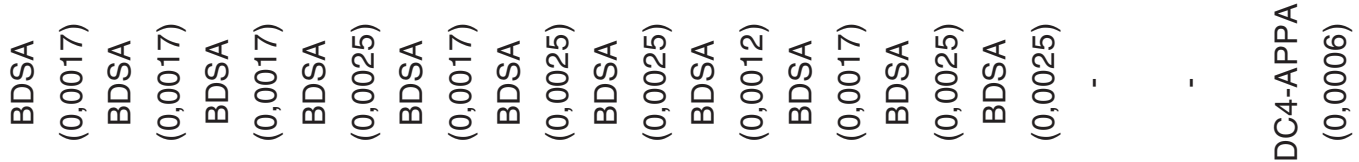

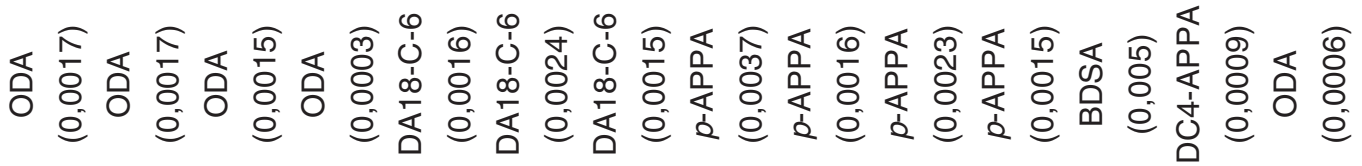

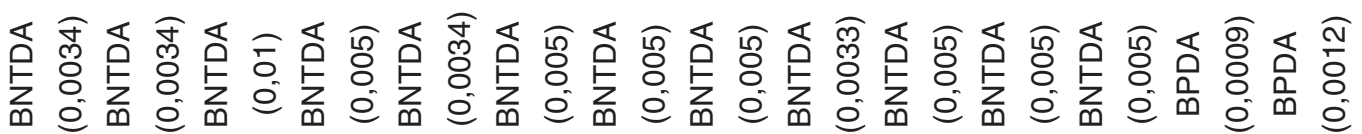

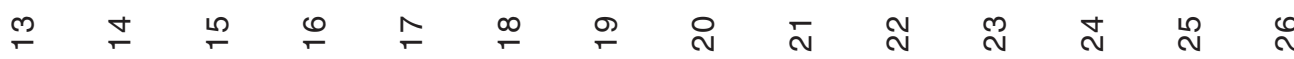


Fig. 2a. illustrate a fragments of ${ }^{1} \mathrm{H}$ NMR spectrums of the polyimides ${ }^{12}$ and 5
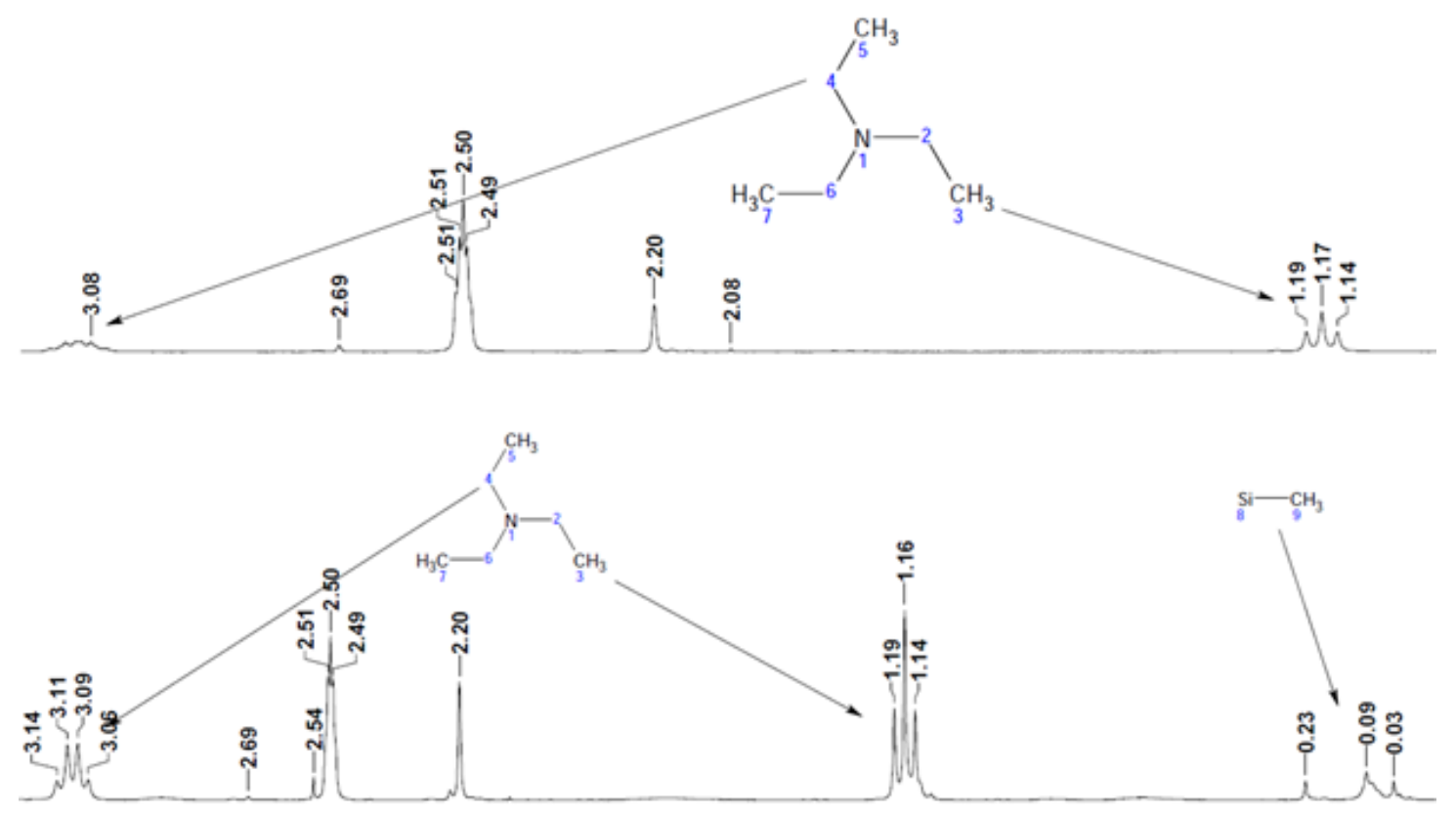

Fig. 2 b. ${ }^{1} \mathrm{H}$ NMR spectra of the polyimides ${ }^{1} 2$ (up) and ${ }^{1} 5$ (down).

Completely soluble $\mathrm{PI}$ is polymer forms a homogeneous solution without any precipitate or suspended matter after dissolution; partially soluble is polymer forms a colored solution with some precipitate or suspended matter; and insoluble is polymer remains unaffected by solvent.

It was found that all of synthesized polyimides are soluble in DMSO, NMP, m-cresol, poorly soluble or completely insoluble in DMF and DMA, and completely insoluble in other tested solvents.

\section{Film-forming ability}

DMSO was selected as the most suitable solvent as all PIs are soluble in it. Moreover, boiling point of DMSO is lower than that of N-MP and it is not toxic by comparison with $m$-cresol. Film-forming ability data are summarized in Table. 2 .

As Table. 2 shows, hard films were obtained starting powdered from PI 2,3,4,10,11 and 24. The data summarized in the table allows to conclude that virtually all films containing BNTDA turned out to be fragile, except for the compound

Table. 3: Thermal and mechanical properties of the films

\begin{tabular}{lcccccc}
\hline Entry & \multicolumn{2}{c}{ Films } & \multicolumn{2}{c}{ Powder } & $\begin{array}{c}\text { Relative } \\
\text { elongation, } \%\end{array}$ & $\begin{array}{c}\text { Tensile } \\
\text { strength, MPa }\end{array}$ \\
\hline 2 & $\mathrm{~T}_{\mathrm{d} 5},{ }^{\circ} \mathrm{C}$ & $\mathrm{T}_{\mathrm{d} 10},{ }^{\circ} \mathrm{C}$ & $\mathrm{T}_{\mathrm{d} 5},{ }^{\circ} \mathrm{C}$ & $\mathrm{T}_{\mathrm{d} 10},{ }^{\circ} \mathrm{C}$ & & \\
\hline 3 & 205 & 268 & 141 & 169 & 14,1 & 1,0 \\
4 & 219 & 354 & 224 & 318 & 2,7 & 2,6 \\
10 & 180 & 333 & 178 & 251 & $\mathrm{~N} / \mathrm{A}^{*}$ & $\mathrm{~N} / \mathrm{A}^{*}$ \\
11 & 197 & 304 & 301 & 335 & 4,9 & 10,2 \\
24 & 189 & 229 & 133 & 203 & 9,6 & 7,0 \\
\hline
\end{tabular}

N/A - data not available 
24, despite their high solubility in DMSO. Any DA 18-C-6 containing polymers also resulted in fragile films. In general, there is a relationship: highly soluble compounds form fragile films. Decreasing of BDSA content in the polyimide composition (see 1, 9, 13, and 20) also leads to fragile films. PDMS, ODA and other diamines in the polyimide composition ambivalently affect to both solubility and film-forming ability.

\section{Thermal and mechanical properties}

Thermal and mechanical properties of the prepared films were investigated. (Table. 3). For the comparative purpose, the $\mathrm{T}_{\mathrm{d} 5}$ and $\mathrm{T}_{\mathrm{d} 10}$ values of the powders the films were measured.

From the TGA curves of all powders and films we can conclude that in the first stage of thermal destruction of membranes, water and/or residual solvents are removed. The next stage of the thermal destruction is the removal of triethylammonium ions, followed by the elimination of the sulfonic acid groups. At temperatures above $370{ }^{\circ} \mathrm{C}$, the main chain of the polymer begins to break down. Table. 3 demonstrate that all the prepared films possess a sufficiently high thermal stability and could be suitable for low-temperature fuel cells (up to $100{ }^{\circ} \mathrm{C}$ ) construction. Moreover majority of prepared films could be used in medium temperature fuel cells $\left(140-200{ }^{\circ} \mathrm{C}\right)$. Additionally, Table. 3 demonstrate the low mechanical properties of films. We will continue development of the technology to prepare strong films, as well as the research to achieve the optimal structure of the polyimide chain for FC membranes producing.

\section{CONCLUSION}

26 different polyimide compounds were prepared by single-stage condensation in a highboiling solvent (m-cresol). The structure of polyimides was characterized and confirmed with NMR- and IR-spectroscopy. Solubility, film-forming ability as well as thermal and mechanical properties were investigated. NDTA-based films demonstrate high thermal stability but low mechanical properties and could be used for low and medium temperature fuel cells construction.

\section{ACKNOWLEDGEMENT}

Applied researches are carried out with state financial support represented by the Ministry of Education of Russia under the agreement on granting subsidies No. 14.625.21.0036 of October 27, 2015. Unique identifier for Applied Scientific Researches (project) RFMEFI62515X0036.

\section{REFERENCES}

1. Savadogo O. J Power Sources., 2004, 127, 135-161

2. Zhang X, Guo J, Chen J., Energy., 2010, 35, 5294-5299.

3. Carton J.G., Olabi A.G. Energy., 2010, 35, 2796-2806.

4. Dobrovolskii Y.A., Pisareva A.V., Leonova L.S., Karelin A.I. International Scientific Jornal for Alternative Energy and Ecology ISJAEE. (Russian)., 2004, 12, 36-41.

5. Gallyamov M.O., Khokhlov A.R. M .: Fizicheskiy fakul'tet MGU (Russian)., 2014. 72 .

6. Dobrovol'skiy Y. A., Volkov Y. V. Pisareva A. V., Fedotov Y. A., Likhachev D. Y., Rusanov A. L. Zhurnal Ros. Khim. Ob-va im. D.I. Mendeleyeva (Russian)., 2006. 6. S.95-104.

7. Sedesheva, Y. S., Ivanov, V. S., Wozniak, A. I., \& Yegorov, A. S. Orient. J. Chem., 2016, 32
(5), 2283-2296.

8. Ivanchev S. S., Myakin S. V. Uspekhi khimii (Russian)., 2010, 79(2), 117-134.

9. Bose, S., Kuila, T., Nguyen, T. X. H., Kim, N. H., Lau, K. T., \& Lee, J. H. Progress in Polymer Science., 2011, 36(6), 813-843.

10. Mauritz K.A., Moore. R. B. Chem. Rev., 2004, 104-162.

11. Wozniak A. I., Yegorov A. S., Ivanov V. S., Igumnov S M., Tcarkova K. V. Journal of Fluorine Chemistry., 2015, 180, 45-54.

12. Sandor, R. B. High Performance Polymers., 1990, 2, 25-37.

13. Seel D.C., Benicewicz B.C., Xiao L., Schmidt T.J., Handbook of Fuel Cells - Fundamentals, Technology and Applications., 2010. 470.

14. Yokokawa H., Gasteiger H.A.. Advances in Electocatalysis, Materials, Diagnostics and 
Durability., 2009, 398.

15. Kraytsberg A., Yair Ein-Eli A. Energy Fuels., 2014, 28, 7303-7330.

16. Nasef M., Saidi H., Yarmo M.A. J. New Mat. Electrochem. Syst., 2000, 3, 309-317

17. Faure S., Cornet N., Gebel G. In: Proc. of the Sec. Int. Symp. on New Materials for Fuel Cell and Modern Battery Systems., 1997, 818.

18. Kerres J., Cui W., Reichle S. Sci. Part A Polym. Chem., 1996. 34, 2421-2438.

19. Bauer Â., Jones D. J., Roziere J. J. New Mater. Electro-chem. Syst., 2000, 3,.93-98.

20. Katime I.A., Iturbe C.C. In: Polymeric Materials Encyclopedia, V. 5 (H-L). Boca Raton. FL. CRC., 1996, 3097-3106.

21. Roziere J., Jones D. J. Annu. Rev. Mater. Res., 2003, 33, 503-555.

22. Wozniak A. I., Ivanov V. S., Kosova O.V., Yegorov A. S. Orient. J. Chem. 2016, 32 (6), 2967-2974.

23. Ivanov V. S., Wozniak A. I., Yegorov A. S. Orient. J. Chem. 2016. 32 (6), 3155-3164.

24. Liaw D.-J., Wang K.-L., Progress in Polymer Science., 2012, 37, 907-974.

25. Vallejo E., Pourcelly G., Gavach C. J. Membrane Sci., 1999, 160, 127-137.

26. Miyatake K., Asano N., Watanabe M. Journal of Polymer Science Part A: Polymer Chemistry., 2003, 41, 3901-3907.

27. Woo Y., Oh S.Y., Kang Y.S., Jung B. J. Membrane Sci., 2003, 220, 31-45.

28. He Y., Tong C., Geng L., Liu L., Lu C. J. Membrane Sci., 2014, 458, 36-46.

29. Negi Y.S., Damkale S.R., Ansari S. J. Macromol Sci Rev Macromol Chem Phys., 2001, 41, 119-138.
30. Ding M.X. Prog Polym Sci. 2007. 32, 623-668.

31. Mittal KL. Polyimides and other high temperature polymers: synthesis, characterization., 2003 , 2., 252.

32. McGrath J. E. Progress in Polyimide Chemistry I. Springer Berlin Heidelberg., 1999, 61-105.

33. Saam J.C., Spier J.L. J Org Chem., 1959, 24, 119-122.

34. Sun F., Wang T., Yang S., Fan L. Polymer., 2010, 51(17), 3887 -3898

35. Berezina R.N., Kobrin V.S., Kusov S.Z., Lubenets E.G. Russian Journal of Organic Chemistry., 1998, 34(10), 1517-1518.

36. Glushko V.N., Tsirul'nikova N.V., Blokhina L.I., Pevtsova L.A., Sadovskaya N.Yu., Fetisova T.S., Podmareva O.N. Zhurn. Naukoyemkiye tekhnologii., 2013, 3, 5-10.

37. Fang J., Guo X., Harada S., Watari T., Tanaka K., Kita H., Okamoto K.-I. Macromolecules. 2002, 35, 9022-9028.

38. Xie C., Sullivan K. A., Laurila M. E., Mitchell D. N., Pu Y. J. Synth. Comm. 2008, 38, 21-32.

39. Zhang X. H., Huang L. H., Chen S., Qi G. R. Express Polym. Lett., 2007, 5, 326-336.

40. Tcarkova K. V., Artyushin O. I., Bondarenko N. A. Phosphorus, Sulfur, and Silicon and the Related Elements.m 2016, 191 (11-12), 1520-1522.

41. Yegorov A.S., Wozniak, A. I., IvanovV.S., Averina, E. A., Zhdanovich, O. A. Orient. J. Chem. +2016, 32 (6), 3063-3070.

42. Lee C.-H., Chen S.-H., Wang Y.-Z., Lin C.-C., Huang C.-K., Chuang C.-N., Wang C.-K., Hsieh K.-H. Energy., 2013, 55, 905-915. 